\title{
Preparation and Irreversible Inhibition Mechanism Insight into a Recombinant Kunitz Trypsin Inhibitor from Glycine max L. Seeds
}

\author{
Yanji Xu ${ }^{1} \cdot$ Panpan Zhang $^{1} \cdot \mathrm{Xiao}_{\mathrm{Liu}^{2}} \cdot$ Zhike Wang $^{2} \cdot$ Suxia $\mathrm{Li}^{1}$
}

Received: 30 November 2017 / Accepted: 5 April 2018 /

Published online: 1 February 2020

(C) The Author(s) 2020

\begin{abstract}
Soybean Kunitz trypsin inhibitor (SKTI), extracted from soybean (Glycine max L.) seeds, possesses insect resistance and anti-tumor properties. But its specific mechanisms of action are not yet known. This article reports an efficient method to produce recombinant SKTI (rSKTI) in Escherichia coli, reveals some biochemical properties of rSKTI, and discusses the inhibition mechanism of SKTI. The rSKTI was expressed as inclusion body in $E$. coli BL21 (DE3). After refolding, the active rSKTI was obtained and was further purified with anion-exchange chromatography (DEAE-FF) efficiently. There were similar biochemical properties between SKTI and rSKTI. The optimum $\mathrm{pH}$ and the optimum temperature were $\mathrm{pH} 8.0$ and $35^{\circ} \mathrm{C}$, respectively, being stable during $\mathrm{pH} 7.0-11.0$ and below $37^{\circ} \mathrm{C}$. The activity against trypsin was inhibited by $\mathrm{Co}^{2+}, \mathrm{Mn}^{2+}, \mathrm{Fe}^{3+}, \mathrm{Al}^{3+}$, and epoxy chloropropane. Inhibition kinetic assay of SKTI against trypsin as LineweaverBurk plots analysis both showed an unchanged $K_{\mathrm{m}}$ and a decreased $V_{\max }$ with $N$-benzoylL-arginine ethyl ester (BAEE) as substrate. Molecular modeling showed Arg63 of SKTI (active residue of SKTI) that interacts with four residues of trypsin, including three catalytic site (His57, Asp102, and Ser195) and one binding site (Asp189), forming five interactions. These provide reference for understanding the inhibition mechanism of such kind of Kunitz trypsin inhibitors.
\end{abstract}

Keywords Soybean Kunitz trypsin inhibitor P Protein refolding · Biochemical property· Inhibition kinetic assay $\cdot$ Molecular modeling

Electronic supplementary material The online version of this article (https://doi.org/10.1007/s12010-02003254-5) contains supplementary material, which is available to authorized users.

Suxia Li

lisuxia@ecust.edu.cn

1 State Key Laboratory of Bioreactor Engineering, East China University of Science and Technology, Shanghai 200237, China

2 Shanghai Yaxin Biotechnology Limited Company, Shanghai 200231, China 


\section{Introduction}

Soybean (Glycine max L.) is one of the most important and widely consumed legume crops in the world. SKTI, a member of the serine protease inhibitor family, is a major anti-nutritional factor in soybean seeds that can inhibit the activity of both trypsin and chymotrypsin $[1,2]$. These inhibitors have been implicated in various physiological functions, such as regulator of endogenous protease, storage proteins, and defense molecules against plant pests and pathogens [3]. In soybean seeds, SKTI is synthesized as a precursor of 217 amino acids that would undergo proteolytic process to remove a signal peptide of 25 amino acid residues at $\mathrm{N}$ terminus and a hydrophobic polypeptide of 11 amino acid residues at $\mathrm{C}$ terminus, yielding a mature peptide of 181 amino acids [4, 5]. The mature inhibitor is described as a low cysteine content forming two disulfide bonds. Kunitz trypsin inhibitors including SKTI have a common structure composed of 12 anti-parallel $\beta$-strands separated by irregular loops [6]. In SKTI, the side chain of Arg63 residue, as an active site residue, carried positive charges, forming strong electrostatic interaction with the negative charge of the side chain of Asp189 in enzyme, significantly contributing to the binding of inhibitor to the active center of trypsin. Figure 1 gives a whole view that the active residue Arg63 of SKTI combines with the active center of trypsin to form a stable enzyme-inhibitor complex. In this article, inhibition kinetics of SKTI to trypsin was investigated; molecular docking technology was adopted to give an explanation of the inhibition mechanism. According to a combination of inhibition kinetic behavior and molecular structure modeling, we concluded that the inhibition type should be an irreversible inhibition instead of a competitive one. This might provide reference for understand the inhibition mechanism of such kind of Kunitz trypsin inhibitors.

Trypsin inhibitors are important biochemical substances. Traditionally, SKTI was extracted from soybean seeds, which limited the large-scale application in agriculture and clinic because of the high costs of preparation [7,8]. With the development of transgenic technology, Escherichia coli host has been widely used as a tool to produce various recombinant protein. Production of recombinant protein provides a suitable method for commercializing medical products [9]. Another advantage of producing recombinant proteins is better safety in comparison with sample expressed from animal cell. Perhaps considering the inhibitory ability of SKTI to serine protease, there were few reports on recombinant expression of SKTI in prokaryote [10]. Fortunately, there have been many studies about recombinant expression of SKTI in plants to harvest the resistant plants [11-14], which provided some guidance and experience for us. Here, we reported $E$. coli system was used to express rSKTI with success. In addition, the refolding conditions of rSKTI inclusion bodies were optimized. The technology would be useful for the production and study of other Kunitz trypsin inhibitors. Biochemical properties of both SKTI and rSKTI were investigated in the research, such as optimum $\mathrm{pH}$ and temperature, stability of $\mathrm{pH}$ and temperature, and inhibition kinetics behavior. Some was first studied and the results should be useful for its application.

\section{Materials and Methods}

\section{Materials}

The synthesis and analysis of SKTI gene sequence were performed by Generay Biotechnology Corporation (Shanghai, China). The recombinant trypsin was acquired 
a
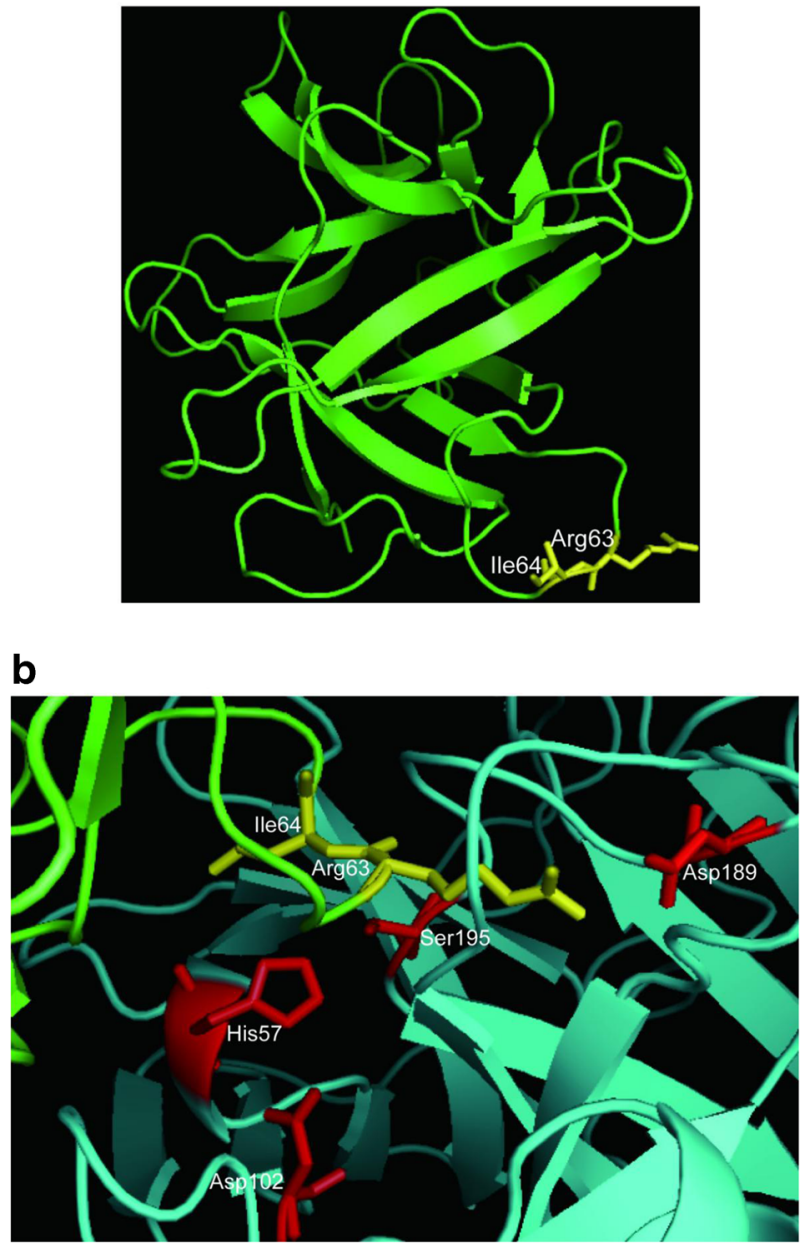

Fig. 1 Three-dimensional model gives a general view. a SKTI (green) and its active sites (yellow). b Showing the interactions between SKTI (yellow) and trypsin (red)

from Yaxin Biotechnology Limited Company (Shanghai, China). The natural soybean Kunitz trypsin inhibitor (SKTI) and $N$-benzoyl-L-arginine ethyl ester (BAEE) were purchased from Sigma Co. (USA). All other reagents were of analytical grade.

\section{Construction of the Expression Strain for rSKTI}

The gene of SKTI was designed according to the codon bias of E. coli and synthesized based on the primary sequence of SKTI from Uniprot database with accession number of P01070. The gene was cloned into pET-28a (+) expression vector (Novagen) using the NdeI (upstream) and HindIII (downstream) cloning sites and then transformed into E. coli (DE3) strains which was held in our laboratory. 


\section{Expression and Refolding of rSKTI}

The E. coli BL21 (DE3) strains were routinely cultivated at $37{ }^{\circ} \mathrm{C}$ in Luria-Bertani medium containing $50 \mu \mathrm{g} / \mathrm{mL}$ kanamycin. When the cells reached a optical density (OD600) of 0.9 with UV spectrophotometry, the cells were induced by isopropyl- $\beta$-D-thiogalactopyranoside (IPTG) with a final concentration of $0.5 \mathrm{mM}$. After growing for an additional $4 \mathrm{~h}$ at $37^{\circ} \mathrm{C}$, the cells were harvested by centrifugation at $6000 \mathrm{rpm}$ for $20 \mathrm{~min}$ and lysed by ultrasonication. Then, inclusion bodies were separated by centrifugation at $12000 \mathrm{rpm}$ for $15 \mathrm{~min}$ at $4{ }^{\circ} \mathrm{C}$. Triton $\mathrm{X}-100(0.5 \%$, $\mathrm{v} / \mathrm{v}$ ) was used as a detergent to purify the inclusion bodies. The inclusion bodies were washed with $20 \mathrm{mM}$ Tris-HCl buffer ( $\mathrm{pH}$ 8.0) three times to eliminate Triton X-100.

Purified inclusion bodies were denatured and then diluted in refolding buffer. The final concentration of protein in the refolding buffer was $1 \mathrm{mg} / \mathrm{mL}$. A L25(56) orthogonal experiment design was adopted to screen three key refolding factors (Table 1). The optimum level for each factor was obtained according to the activity of rSKTI after refolding. Single-factor experiment was further optimized to achieve the higher yield.

\section{Purification of rSKTI}

The refolded rSKTI was purified by DEAE-FF anion-exchange chromatography (Best Chrom, China). The activated rSKTI was eluted from the column by a linear $0-500 \mathrm{mM} \mathrm{NaCl}$ gradient in $20 \mathrm{mM}$ Tris- $\mathrm{HCl}, \mathrm{pH} 8.0$. The samples with activity were pooled and stored at $-20{ }^{\circ} \mathrm{C}$ for further study.

\section{SKTI Activity Assay}

SKTI activity assay method is based on the United States Pharmacopoeia (USP) with a little modification [15]; its activity against trypsin was assayed based on the activity difference of trypsin in the absence or presence of SKTI. The trypsin activity from the positive control group (without SKTI) and the experiment group (with SKTI) was measured in $67 \mathrm{mM}$ phosphate buffer $(\mathrm{PB}, \mathrm{pH} 7.6)$ at $25^{\circ} \mathrm{C}$ with BAEE as substrate. Here, the positive control group consisted of $50 \mu \mathrm{L} 1.35 \mathrm{mg} / \mathrm{mL}$ trypsin and $950 \mu \mathrm{L}$ $67 \mathrm{mM} \mathrm{PB}, \mathrm{pH}$ 7.6. The experiment group consisted of $50 \mu \mathrm{L} 1.35 \mathrm{mg} / \mathrm{mL}$ trypsin, $50 \mu \mathrm{L} 0.63 \mathrm{mg} / \mathrm{mL}$ SKTI, and $900 \mu \mathrm{L} 67 \mathrm{mM} \mathrm{PB}, \mathrm{pH}$ 7.6. One trypsin inhibitor unit (EPU) is defined that will decrease the activity of two trypsin units by $50 \%$ where one trypsin unit is defined that will hydrolyze $1.0 \mu \mathrm{mol}$ of BAEE per second in $\mathrm{pH}$ 7.6 at $25{ }^{\circ} \mathrm{C}$. The activity of SKTI was calculated as follows.

Table 1 Orthogonal design of rSKTI refolding condition

\begin{tabular}{llll}
\hline Levels & \multicolumn{2}{l}{ Factors } & \\
\cline { 2 - 4 } & $\mathrm{pH}$ & Temperature $\left({ }^{\circ} \mathrm{C}\right)$ & Redox couple (GSH+GSSG, mM) \\
\hline 1 & 8.5 & 4 & $0+0$ \\
2 & 9.0 & 10 & $1+0$ \\
3 & 9.5 & 16 & $1+0.125$ \\
4 & 10.0 & 23 & $1+0.25$ \\
5 & 10.5 & 30 & $4+1$ \\
\hline
\end{tabular}


Activity of SKTI $(\mathrm{EPU} / \mathrm{L})=\frac{\Delta \mathrm{A}_{253, \mathrm{U} 0}-\Delta \mathrm{A}_{253, \mathrm{U} 1}}{0.001 \times 270 \times 60 \times \mathrm{t} \times \mathrm{V}} \times \mathrm{df} \times 1000$

where $\triangle A 253, \mathrm{U} 0$ and $\triangle A 253, \mathrm{U} 1$ are the change of absorbance at $253 \mathrm{~nm}$ within schedule time from the positive control group and the experiment group, respectively; $t$ is the reaction time, $3 \mathrm{~min} ; V$ is the volume of reaction solution, $100 \mu \mathrm{L} ; 0.001$ is the change in absorbance, corresponding to one trypsin unit; 270 is conversion coefficient of FIP unit, one FIP unit is equal to 270 BAEE units; 60 is conversion coefficient of EPU unit, one EPU unit is equal to 60 FIP units; df is dilution factor of SKTI in reaction solution, 20; and 1000 is the conversion coefficient of volume unit.

Protein content was measured according to the BCA method [16], using bovine serum albumin as the standard protein. All assays were performed in triplicate.

\section{Biochemical Properties}

\section{Effects of Temperature on Activities and Stabilities of SKTI and rSKTI}

The effects of temperature on the activities of SKTI and rSKTI were investigated. Both the positive control group $\mathrm{U} 0(1.35 \mathrm{mg} / \mathrm{mL}$ trypsin in $67 \mathrm{mM} \mathrm{PB}, \mathrm{pH}$ 7.6.) and the experiment group U1 (1.35 mg/mL trypsin plus $0.63 \mathrm{mg} / \mathrm{mL}$ SKTI in $67 \mathrm{mM} \mathrm{PB}, \mathrm{pH} 7.6)$ were incubated in a different temperature, ranging from 4 to $65^{\circ} \mathrm{C}$ and then kept for $2 \mathrm{~h}$. The remained trypsin activity was measured and inhibitory activity of SKTI was calculated as described in "SKTI Activity Assay." The inhibition rate was calculated based on the following equation. The results are expressed as the mean value \pm S.D. of triplicate assay.

$$
\text { Inhibition rate }=(1-\mathrm{U} 1 / \mathrm{U} 0) \times 100 \%
$$

where U0 and U1 are the activity of trypsin in the positive control group and the experiment group, respectively.

For the thermal stability of SKTI and rSKTI, $0.63 \mathrm{mg} / \mathrm{mL}$ SKTI or rSKTI in $67 \mathrm{mM} \mathrm{PB}$, $\mathrm{pH}$ 7.6) was incubated in a different temperature as above. The trypsin activity was measured and inhibitory activity of SKTI was calculated as described in "SKTI Activity Assay." The results are expressed as the mean value \pm S.D. of triplicate assay.

\section{Effects of pH on Activities and Stabilities of SKTI and rSKTI}

The effects of $\mathrm{pH}$ on the activities of SKTI and rSKTI were investigated. Both the positive control group U0 $(1.35 \mathrm{mg} / \mathrm{mL}$ trypsin) and the experiment group U1 $(1.35 \mathrm{mg} / \mathrm{mL}$ trypsin plus $0.63 \mathrm{mg} / \mathrm{mL}$ SKTI) were prepared in different $\mathrm{pH}$ buffers, including $100 \mathrm{mM} \mathrm{HAc}-\mathrm{NaAc}$ (pH 3.0-6.0), $100 \mathrm{mM}$ Tris- $\mathrm{HCl}(\mathrm{pH} 7.0-8.0)$ and $100 \mathrm{mM}$ Gly-NaOH (pH 9.0-11.0), and then kept at $25{ }^{\circ} \mathrm{C}$ for $12 \mathrm{~h}$. The remained trypsin activity was measured and inhibitory activity of SKTI was calculated as described in "SKTI Activity Assay." The inhibition rate was calculated based on the Eq. (2). The results are expressed as the mean value \pm S.D. of triplicate assay.

For the pH stability of SKTI and rSKTI, both $0.63 \mathrm{mg} / \mathrm{mL}$ SKTI and rSKTI were incubated in above buffer solutions at $25^{\circ} \mathrm{C}$ for $12 \mathrm{~h}$. The trypsin activity was measured and inhibitory activity of SKTI was calculated as described in "SKTI Activity Assay." The results are expressed as the mean value \pm S.D. of triplicate assay. 


\section{Effects of Metal lons and Organic Solvents on Stabilities of SKTI and rSKTI}

The concentration of $100 \mathrm{mM}$ various types of metal ion solutions was prepared including $\mathrm{Ca}^{2+}, \mathrm{Ba}^{2+}, \mathrm{Mg}^{2+}, \mathrm{Co}^{2+}, \mathrm{Cu}^{2+}, \mathrm{Mn}^{2+}, \mathrm{Ni}^{2+}, \mathrm{Fe}^{3+}, \mathrm{Zn}^{2+}$, and $\mathrm{Al}^{3+}$. Both $0.63 \mathrm{mg} / \mathrm{mL}$ SKTI and rSKTI were prepared in $67 \mathrm{mM}$ Tris- $\mathrm{HCl}$ buffer ( $\mathrm{pH}$ 7.6) with above metal ion solutions at the final concentration of $1 \mathrm{mM}$ at $25{ }^{\circ} \mathrm{C}$ for $4 \mathrm{~h}$.

Both SKTI and rSKTI $(0.63 \mathrm{mg} / \mathrm{mL})$ were prepared with various types of organic solvents at the final concentration of $10 \%(\mathrm{v} / \mathrm{v})$, including dimethyl sulfoxide (DMSO), methanol $(\mathrm{MeOH})$, ethanol $(\mathrm{EtOH})$, acetonitrile $(\mathrm{ACN})$, glycerin, acetone, epoxy chloropropane (EPI), diisopropyl ether (DIPE), and isoamyl alcohol (IAOH), and kept at $25^{\circ} \mathrm{C}$ for $4 \mathrm{~h}$.

The trypsin activity was measured and inhibitory activity of SKTI was calculated as described in "SKTI Activity Assay." The only difference is that $67 \mathrm{mM}$ PB buffer (pH 7.6) is substituted with $67 \mathrm{mM}$ Tris-HCl buffer $(\mathrm{pH}$ 7.6) for activity assay. The results are expressed as the mean value \pm S.D. of triplicate assay.

\section{Kinetic Parameter Assay}

The kinetic parameters including Michaelis constant $(\mathrm{Km})$ and maximal velocity $\left(V_{\max }\right)$ were determined based on the Michaelis-Menten equation by Lineweaver-Burk method in the presence and absence of inhibitor. The various substrate concentrations of BAEE was $0.01 \mathrm{mM}, 0.015 \mathrm{mM}, 0.02 \mathrm{mM}, 0.03 \mathrm{mM}, 0.05 \mathrm{mM}$, and $0.075 \mathrm{mM}$. All assays were performed in triplicate at $25^{\circ} \mathrm{C}$ in $67 \mathrm{mM} \mathrm{PB} \mathrm{(pH} \mathrm{7.6).} \mathrm{The} \mathrm{value} \mathrm{of} \mathrm{the} \mathrm{inhibition} \mathrm{constant}$ $(K \mathrm{I})$ was calculated by the following equation:

$$
V_{\max } / V_{\max }^{\prime}=1+{ }^{[I]} / K_{I}
$$

where $V_{\max }$ and $V_{\max }^{\prime}$ are the maximum of activated trypsin activity in the absence and presence of inhibitor, respectively; $[I]$ is the concentration of inhibitor; and $K I$ is the inhibition constant.

\section{Molecular Modeling}

SWISS-MODEL (http://swissmodel.expasy.org/) was used for homologous modeling of the SKTI and trypsin. AutoDock Vina (http://vina.scripps.edu/) was used to protein-protein molecular docking and screens the feasible results. All PDB files of protein structures were visualized on PyMol (http://pymol.sourceforge.net/).

\section{Results}

\section{Expression of rSKTI}

SDS-PAGE analysis of the expression of rSKTI in E. coli BL21 (DE3) showed a significant protein band of about $20.1 \mathrm{kDa}$, corresponding to the theoretical molecular weight of rSKTI (Fig. 2). In the analysis on soluble and insoluble parts after cell disruption with ultrasonication, the aimed protein band was mainly appeared in insoluble part, indicating it was expressed as inclusion body (Fig. 2, line 4). 
Fig. 2 Fifteen percent of SDSPAGE analysis of the expression of rSKTI from E. coli. Line M, molecular weight marker; line 1, cell lysate before induction; line 2, cell lysate after $0.5 \mathrm{mM}$ IPTG induction; line 3 , soluble protein; line 4 , insoluble protein

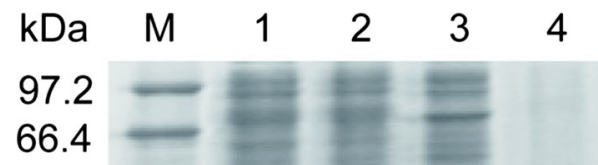

44.3

29.0

20.1

14.3

\section{Optimizing Refolding of rSKTI}

Several key factors that influenced the refolding such as $\mathrm{pH}$, temperature, and redox couples were selected for orthogonal experiment. The analysis of effect of each factor on refolding is shown in Fig. 3, which is based on 25 separated groups of orthogonal design. The optimal condition for rSKTI refolding was $\mathrm{pH} 9.5,16{ }^{\circ} \mathrm{C}, 1 \mathrm{mM} \mathrm{GSH}$ and $\mathrm{pH} 9.5,23{ }^{\circ} \mathrm{C}, 1 \mathrm{mM} \mathrm{GSH}$.

Based on the orthogonal results, a more detailed single-factor experiment was designed to further optimize the refolding condition, such as refolding buffer $\mathrm{pH}$, temperature, and Gly$\mathrm{NaOH}$ buffer concentration. The results are shown in Fig. 4 a, b, and c, respectively. Considering that the denature condition would have effects on its refolding recovery, the key factors were investigated, such as concentration of $\beta$-mercaptoethanol and inclusion body in denature buffer. The results are shown in Fig. $4 \mathrm{~d}$ and e.

Taken these, a final condition was established for rSKTI unfolding and refolding. The rSKTI inclusion bodies $(10 \mathrm{mg} / \mathrm{mL})$ was dissolved in denaturation buffer $(50 \mathrm{mM}$ Gly- $\mathrm{NaOH}$, $8 \mathrm{M}$ urea, $10 \mathrm{mM}$ EDTA, and $5 \mathrm{mM} \beta$-mercaptoethanol, $\mathrm{pH} 9.5$ ) for $2 \mathrm{~h}$ and then diluted in refolding buffer (50 mM Gly-NaOH, $1 \mathrm{mM}$ EDTA, and $1 \mathrm{mM} \mathrm{GSH}, \mathrm{pH} 9.5)$ with a ratio of $1: 10$ (v:v) at $20{ }^{\circ} \mathrm{C}$ for $20 \mathrm{~h}$.

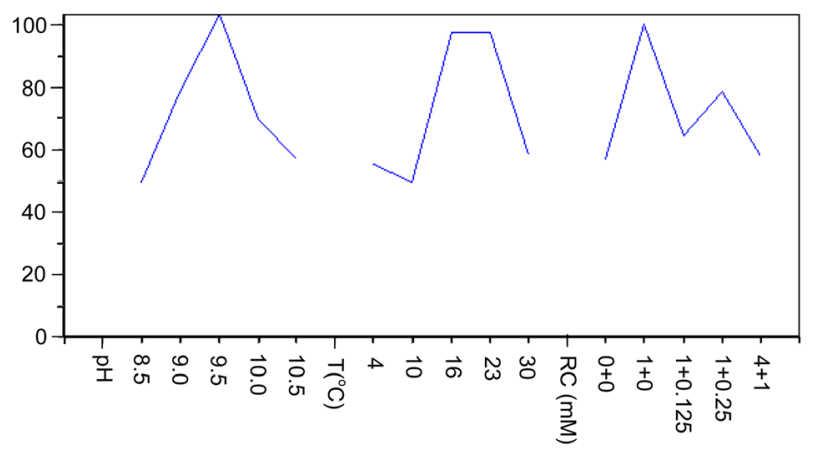

Fig. 3 Effects of $\mathrm{pH}$, temperature (T) and redox couple (RC, GSH + GSSG) on the activity of rSKTI in refolding buffer. Ten milligrams per milliliter of rSKTI inclusion bodies (wet weight) was dissolved in denaturating buffer and then diluted in refolding buffer (1:10 ratio) 
a
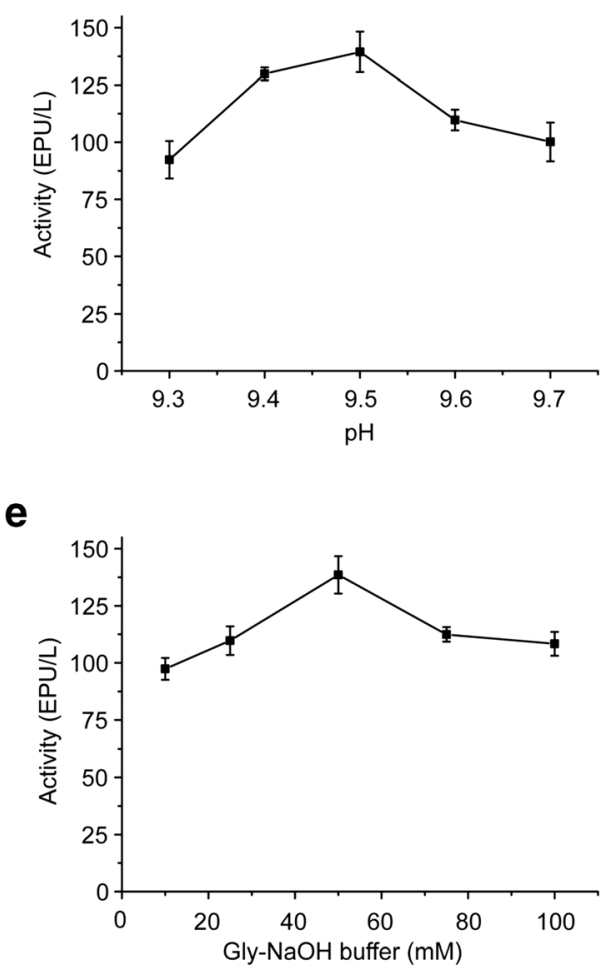

e

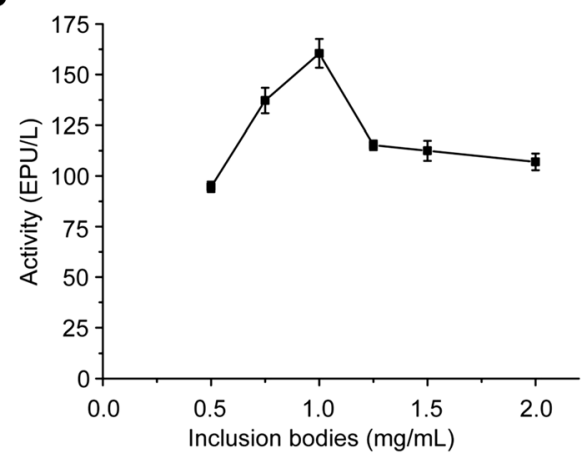

b

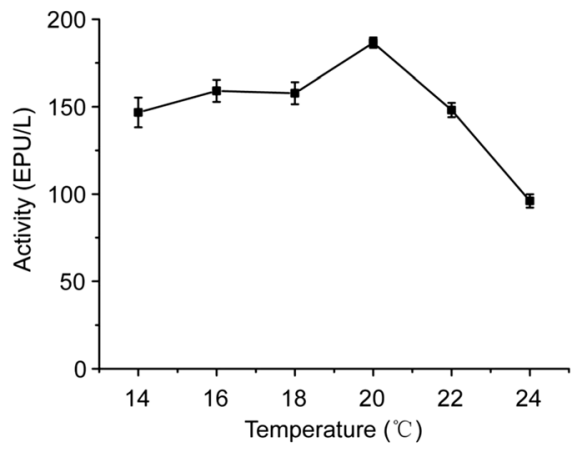

d

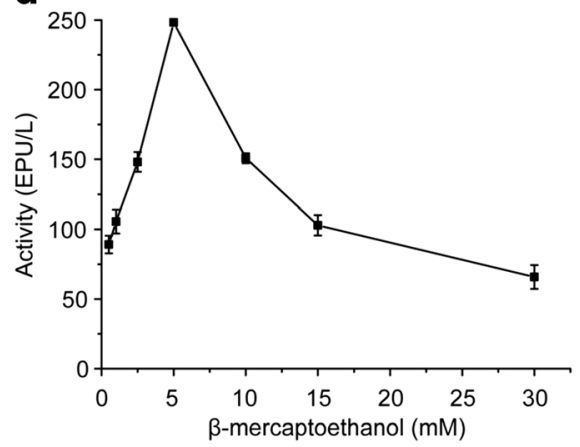

Fig. 4 Optimization of various factors on rSKTI refolding. a pH. b Temperature. c Concentration of Gly-NaOH buffer. $\mathbf{d}$ Concentration of $\beta$-mercaptoethanol. e Contents of inclusion bodies. The results of each series were expressed as the mean \pm S.D. of triplicate assays

\section{Purification of rSKTI}

DEAE-FF anion-exchange chromatography was used to concentrate and purify active rSKTI successfully. The eluents were highly pure, as shown by $15 \%$ SDS-PAGE analysis (Fig. 5). The final activity yield of rSKTI achieved 70\%, and the specific activity of rSKTI was improved over three fold after purification. All data are summarized in Table 2. The samples 
a
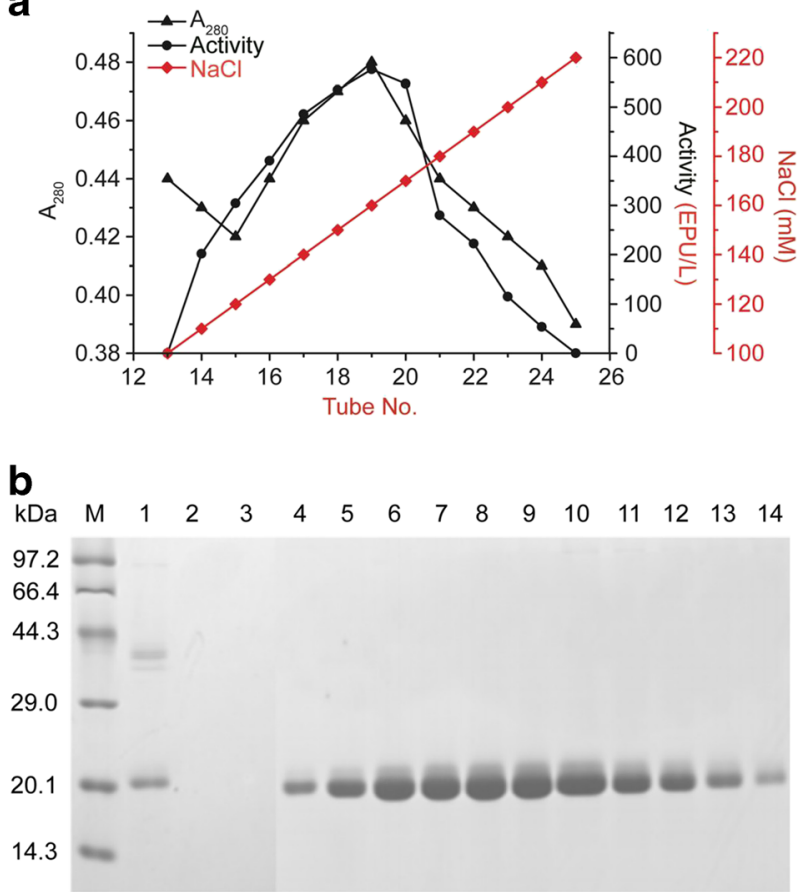

Fig. 5 Purification of rSKTI with DEAE-FF anion-exchange chromatography. a The elution curve of rSKTI. The sample was eluted with a linear gradient of $0-500 \mathrm{mM} \mathrm{NaCl}$ in $20 \mathrm{mM}$ Tris- $\mathrm{HCl}$ buffer $(\mathrm{pH} 8.0)$. b Fifteen percent of SDS-PAGE analysis of eluate samples. Lane M, molecular weight marker; lane 1, loaded sample; lane 2, flow through sample when loading; lane 3, flow through sample at equilibrium; lane $4 \sim 14$, the purified rSKTI protein

from tube no. 14 to tube no. 24 with activity were pooled and concentrated with ultrafiltration. The rSKTI was $1.9 \mathrm{mg} / \mathrm{mL}$ after concentration.

\section{RSKTI Activity Assay}

IC50 value, defined as the amount of rSKTI when half trypsin activity was inhibited, was about $0.5 \mathrm{mg} / \mathrm{mL}$. Moreover, the trypsin activity was completely inhibited by rSKTI at the concentration of $1.5 \mathrm{mg} / \mathrm{mL}$ (Fig. 6). There existed a stable binary complex formed between rSKTI and trypsin with equimolar amount based on the concentration of trypsin and rSKTI.

Table 2 Summary of rSKTI purification

\begin{tabular}{lllllll}
\hline Step & $\begin{array}{l}\text { Volume } \\
(\mathrm{mL})\end{array}$ & $\begin{array}{l}\text { Total } \\
\text { activity } \\
(\text { EPU })\end{array}$ & $\begin{array}{l}\text { Total } \\
\text { protein } \\
(\mathrm{mg})\end{array}$ & $\begin{array}{l}\text { Specific } \\
\text { activity } \\
(\text { EPU/mg pro })\end{array}$ & $\begin{array}{l}\text { Yield of } \\
\text { protein } \\
(\%)\end{array}$ & $\begin{array}{l}\text { Yield of } \\
\text { activity } \\
(\%)\end{array}$ \\
\hline $\begin{array}{l}\text { Before } \\
\text { purification }\end{array}$ & 200 & 53.50 & 100.45 & 0.53 & 100 & 100 \\
\begin{tabular}{l} 
After purification \\
\hline
\end{tabular} & 110 & 37.13 & 30.95 & 1.68 & 30.81 & 69.40 \\
\hline
\end{tabular}


Fig. 6 Inhibitory effect of rSKTI against trypsin. Trypsin $(1.35 \mathrm{mg}$ / $\mathrm{mL}$ ) was inhibited by increasing the contents of rSKTI. The value of $100 \%$ activity refers to trypsin activity without rSKTI. Each value represents an experiment performed in a triplicate (mean \pm S.D.)

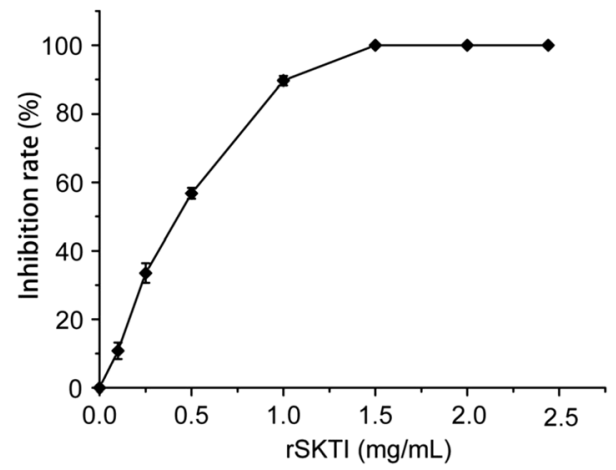

\section{Biochemical Properties}

\section{Effects of Temperature on Activities of SKTI and rSKTI}

When temperature rose from 4 to $65{ }^{\circ} \mathrm{C}$, the activity of trypsin from positive control group (trypsin without SKTI or rSKTI) increased followed by decreased and reached the maximum at $37^{\circ} \mathrm{C}$. Meanwhile, the activity of trypsin from treatment group (trypsin containing SKTI or rSKTI) was almost consistent. The optimum temperature of inhibitor including SKTI and wild type was $35^{\circ} \mathrm{C}$ (Fig. 7a). It was noticeable that both SKTI and wild type have completely lost activity against trypsin when temperature was over $65^{\circ} \mathrm{C}$.

\section{Thermal Stability of SKTI and rSKTI}

The SKTI and rSKTI were quite stable below $37{ }^{\circ} \mathrm{C}$ (Fig. 7b). After incubation for $12 \mathrm{~h}$ at $50{ }^{\circ} \mathrm{C}$, rSKTI retained $50 \%$ of its activity. In contrast, SKTI retained more than $60 \%$ of its activity. After incubation for $12 \mathrm{~h}$ at $65^{\circ} \mathrm{C}$, rSKTI has completely lost activity against trypsin and SKTI merely retained approximately $15 \%$ of its original activity. There were not significant different between the stabilities of SKTI and rSKTI.

\section{Effects of pH on Activities of SKTI and rSKTI}

Using BAEE as the substrate, the optimal $\mathrm{pH}$ was determined to be $\mathrm{pH} 8.0$ for SKTI and rSKTI (Fig. 7c). With the increase of pH, the inhibitory activity of rSKTI was rose followed by declined and reached the maximum at $\mathrm{pH}$ 8.0. In acid condition such as below $\mathrm{pH} 4.0$, rSKTI showed no activity against trypsin. The rSKTI could not bind to trypsin because the side chain of Asp189 residue in active center of trypsin was protonized. Almost, the same tendency and the same optimum $\mathrm{pH}$ of SKTI were obtained.

\section{pH Stability of SKTI and rSKTI}

The rSKTI was stable in $\mathrm{pH} 7.0-11.0$; above $90 \%$ activities were kept, while in $\mathrm{pH} 3.0$ and $\mathrm{pH}$ 4.0 buffers, $50 \%$ and $30 \%$ activity was lost, respectively. Therefore, we concluded that rSKTI was stable in neutral and alkaline conditions (Fig. 7d). At the same time, the same tendency of $\mathrm{pH}$ stabilities of SKTI was obtained. 

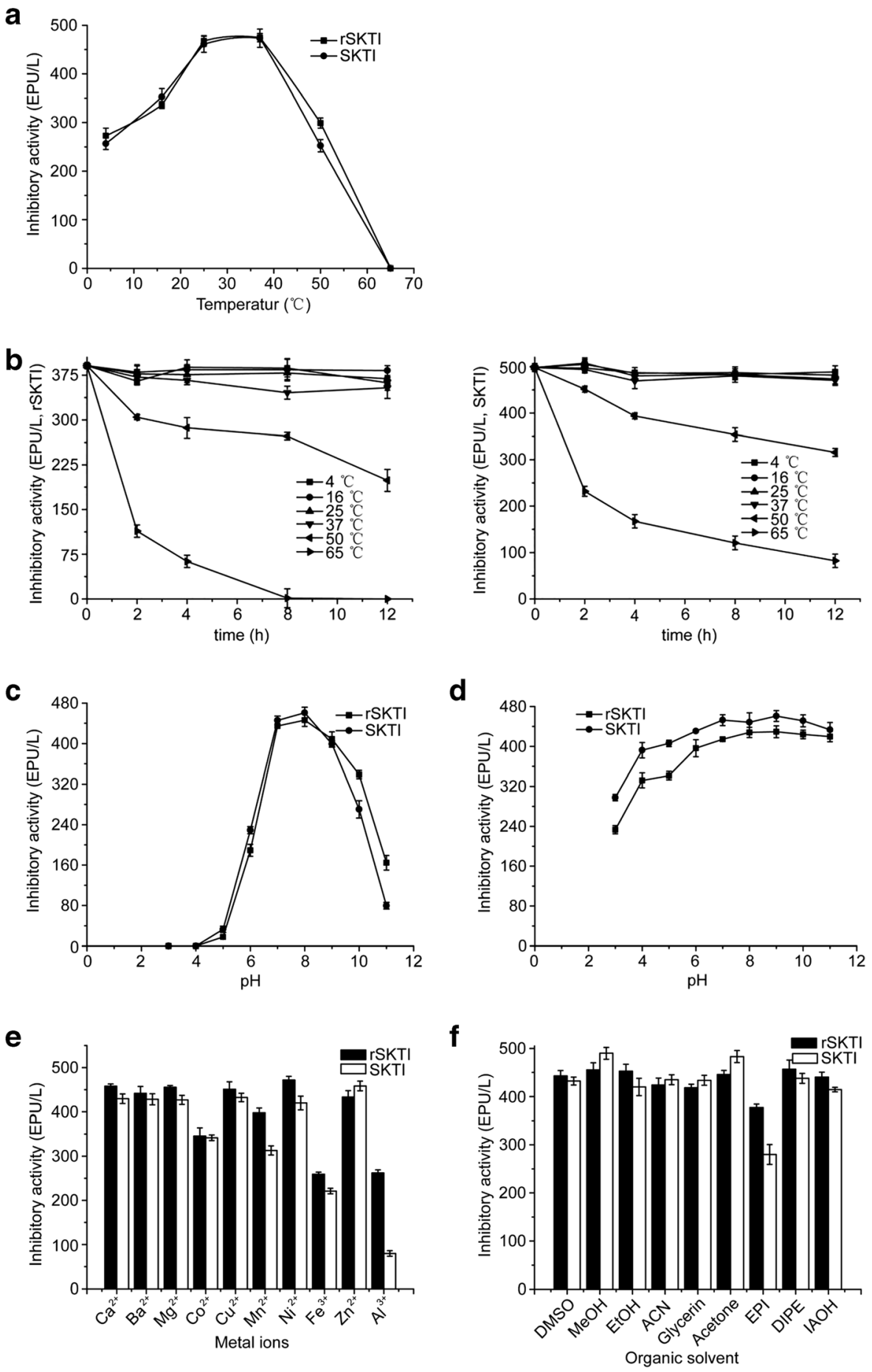

Fig. 7 Biochemical properties of SKTI and rSKTI. a Optimal temperature. b Thermal stability. c Optimal pH. d $\mathrm{pH}$ stability. e Metal ions. $\mathbf{f}$ Organic solvents. The results of each series were expressed as the mean \pm S.D of triplicate assays 


\section{Effects of Metal lons and Organic Solvents on Stabilities of SKTI and rSKTI}

We observed that the activity of inhibitor against trypsin-like was inhibited by $\mathrm{Co}^{2+}, \mathrm{Mn}^{2+}, \mathrm{Fe}^{3+}$, and $\mathrm{Al}^{3+}$, while it was less affected by other metal ions (Fig. 7e). The activity of rSKTI was reduced to $80 \%$ by $\mathrm{Co}^{2+}, 85 \%$ by $\mathrm{Mn}^{2+}$, and $60 \%$ by $\mathrm{Fe}^{3+}$ and $\mathrm{Al}^{3+}$. Similarly, the activity of wild type was reduced to $85 \%$ by $\mathrm{Co}^{2+}, 75 \%$ by $\mathrm{Mn}^{2+}, 65 \%$ by $\mathrm{Fe}^{3+}$, and $30 \%$ by $\mathrm{Al}^{3+}$. The $\mathrm{Co}^{2+}$ and $\mathrm{Mn}^{2+}$, which belonged to heavy metal ions, made protein denatured. The $\mathrm{Fe}^{3+}$ made protein oxidated with extremely strong oxidability. The $\mathrm{Al}^{3+}$ was easily combined with protein, affecting the catalytic reactions involved in the enzyme. In general, organic solvents had little effect on the activity of inhibitor (SKTI and rSKTI), which might be that the hydrolysis reaction of trypsin mainly occurred in aqueous phase instead of in organic phase (Fig. 7f). However, the activity of rSKTI and SKTI was reduced to $85 \%$ and $75 \%$ by epichlorohydrin, respectively.

\section{Kinetic Parameter Assay}

Kinetic parameters of trypsin in the presence and absence of inhibitors (SKTI or rSKTI) were determined, and the results are shown in Fig. 8. The $K \mathrm{~m}$ values of three groups were same, while the $V_{\max }$ values of three groups were different (Table 3). This indicated that the incorporation of SKTI to trypsin did not alter the affinity between trypsin and substrate but reduced the catalytic reaction rate of trypsin. It could be induced that the inhibition type was belong to a non-competitive inhibition. The $K I$ value was calculated as $2.2 \mu \mathrm{M}$ and $1.67 \mu \mathrm{M}$ for rSKTI and SKTI, respectively. The specific activity of rSKTI was $0.71 \mathrm{EPU} / \mathrm{mg}$ pro, lower than that of SKTI $(0.85 \mathrm{U} / \mathrm{mg}$ pro). Perhaps, higher purity for rSKTI attributed to a lower KI value compared with SKTI.

\section{Discussion}

In this study, the results of inhibition kinetic assay as Lineweaver-Burk plots analysis of rSKTI against trypsin showed an unchanged $K \mathrm{~m}$ and decreased $V_{\max }$ value of trypsin. The inhibition mechanism of rSKTI against trypsin might be non-competitive even if more amounts of substrates existed. In addition, the $K I$ value of rSKTI was $2.29 \mu \mathrm{M}$, which was far less than $\mathrm{Km}$ value of trypsin that was $0.02 \mathrm{mM}$. All above suggested that the inhibition of rSKTI to

Fig. 8 Lineweaver-Burk plots analysis of the inhibition kinetics. Assay of the trypsin $(1.35 \mathrm{mg} / \mathrm{mL})$ activity in the presence and absence of SKTI $(0.63 \mathrm{mg} / \mathrm{mL})$ or rSKTI $(0.63 \mathrm{mg} / \mathrm{mL})$

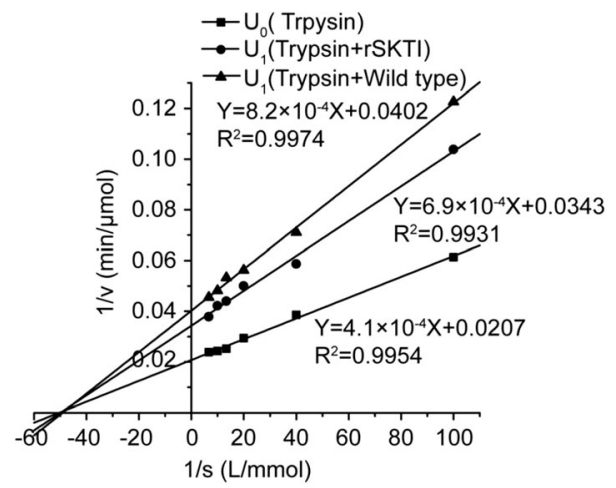


Table 3 Kinetic parameters of trypsin in various conditions

\begin{tabular}{lll}
\hline Group & $K_{\mathrm{m}}(\mathrm{mM})$ & $V_{\max }(\mu \mathrm{mol} / \mathrm{min})$ \\
\hline Trypsin (U0) & 0.02 & 48.31 \\
Trypsin + rSKTI (U1) & 0.02 & 29.15 \\
Trypsin + SKTI (U1) & 0.02 & 24.87 \\
\hline
\end{tabular}

a

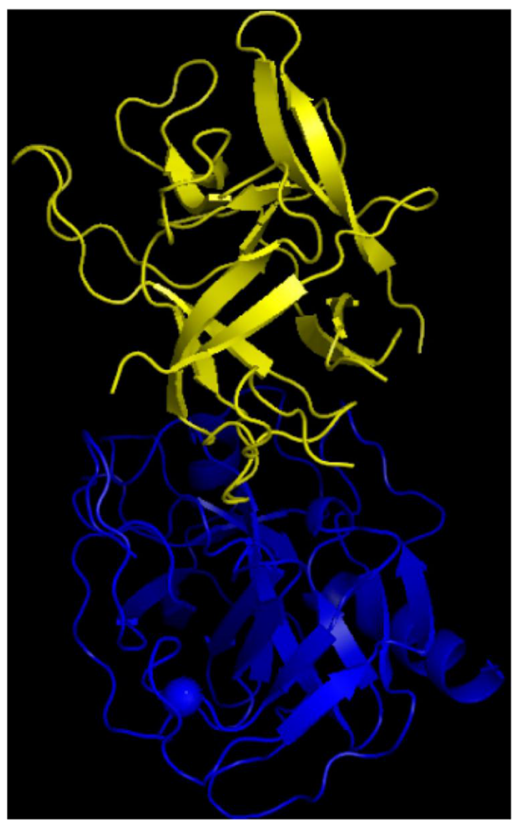

b

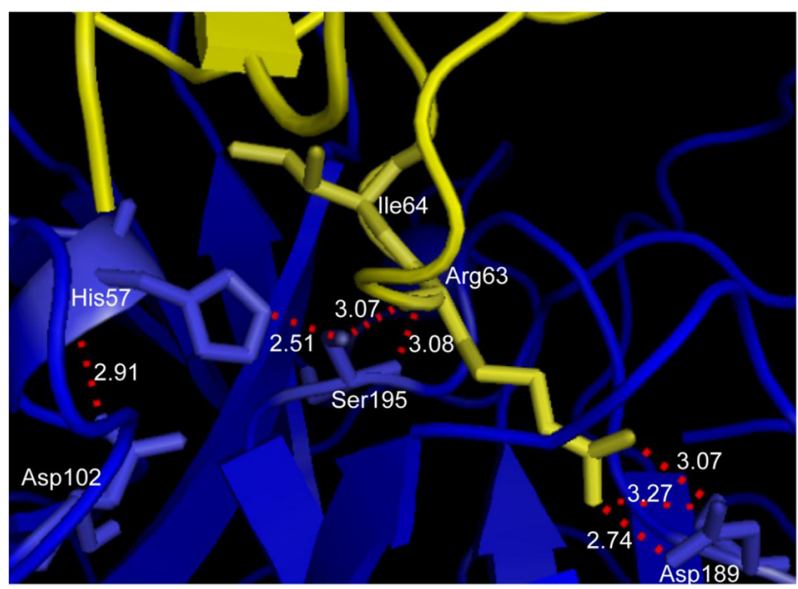

Fig. 9 Three-dimensional model of interaction SKTI (yellow) with trypsin (blue). a Visualization of the binary complex in SKTI-trypsin. b The distance of hydrogen bonds formed by the residues in active region. The inhibitor and proteinase backbone is shown as cartoon. Sticks indicate residues involved in enzyme-inhibitor interaction 
trypsin was more likely to be irreversible type instead of non-competitive type. It was contrary to the previous report that the SKTI was a competitive inhibitor to trypsin [17].

For the inhibition mechanism between inhibitor and enzyme, it was generally accepted that the side chain of Arg63 residue in SKTI carried the positive charges, forming strong electrostatic interaction with the negative charges of the side chain of Asp189 in trypsin, significantly contributing to the binding of inhibitor to the active center of trypsin $[18,19]$. Here, three-dimensional structure of compound is shown in Fig. 9. It was interesting to note that SKTI formed a binary complex with trypsin at the ratio of 1:1 (mol:mol), which was confirmed by trypsin inhibition assay in vitro. Figure $9 \mathrm{~b}$ highlights the interaction between SKTI and trypsin in detail with molecular docking technology. We observed that there were five interactions between Arg63 of SKTI and active domain of trypsin, including three catalytic sites (His57, Asp102, and Ser195) and one binding site (Asp189). It successfully blocked the active center of trypsin and effectively prevented the binding of substrates to trypsin. The side chain guanidine group of Arg63 in SKTI was hydrogen-bonded to the side chain carboxyl group of Asp189 in trypsin, with distance of $2.74 \AA, 3.07 \AA$, and $3.27 \AA$, respectively. In addition, the side-chain hydroxyl group of Ser195 in trypsin acted as a proton donor, while the main chain NH of Arg63 in SKTI acted as a related receptor, at a distance of $3.07 \AA$. The main $\mathrm{NH}$ of Ser195 from trypsin interacted with the main $\mathrm{CO}$ of Arg63 in SKTI, forming a hydrogen bond of $3.08 \AA$.

Combining above three-dimensional structure analysis with inhibition kinetics behavior gave evidences that the inhibition mechanism of SKTI to trypsin should be irreversible. The fact that $K \mathrm{I}$ value of inhibitor was far less than $K \mathrm{~m}$ value of enzyme suggested that SKTI had better affinity and more easily bound to trypsin compared with substrate. Rühlmann et al. [20] found that there was a covalent bond between bovine pancreatic trypsin inhibitor (BPTI) and trypsin based on the electron density at the active region of tetrahedral intermediate, whereas the peptide bond of Lys15-Ala16 at the active site of BPTI was still linked. Later, the research [21] discovered that the scissile peptide bond of SKTI between Arg63 and Ile64 was cleaved by trypsin, because it could specifically digest the peptide bond formed by alkaline amino acid (lysine and arginine) at carboxyl terminus. According to the catalytic mechanism of trypsin to SKTI was analogous to synthetic substrate (BAEE), we further speculated that SKTI was the part of Kcat type inhibitors in terms of trypsin. Of course, further study was needed to validate the hypothesis.

\section{Conclusion}

In this research, an efficient method was established to produce rSKTI in E. coli with optimized refolding technology. Biochemical properties of rSKTI studied here should be useful for the better application of rSKTI in production. Furthermore, the specific study on inhibition kinetic behavior and molecular structure modeling of complex gave new insight into inhibition mechanism of SKTI against trypsin. These results provide reference to further research on the inhibition of other Kunitz trypsin inhibitors to their target protease.

Funding Information This study was partial financially supported by the State Key Laboratory of Bioreactor Engineering (No. 2060204), East China University of Science and Technology. 


\section{Compliance with Ethical Standards}

Conflict of Interest The authors declare that they have no competing interests.

Open Access This article is licensed under a Creative Commons Attribution 4.0 International License, which permits use, sharing, adaptation, distribution and reproduction in any medium or format, as long as you give appropriate credit to the original author(s) and the source, provide a link to the Creative Commons licence, and indicate if changes were made. The images or other third party material in this article are included in the article's Creative Commons licence, unless indicated otherwise in a credit line to the material. If material is not included in the article's Creative Commons licence and your intended use is not permitted by statutory regulation or exceeds the permitted use, you will need to obtain permission directly from the copyright holder. To view a copy of this licence, visit http://creativecommons.org/licenses/by/4.0/.

\section{References}

1. Gupta, Y. P. (1987). Anti-nutritional and toxic factors in food legumes: a review. Plant Foods for Human Nutrition, 37(3), 201-228.

2. Liener, I. E. (1989) Antinutritional factors in legume seeds: state of the art. 1. International Workshop on 'Antinutritional Factors (ANF) in Legume Seeds', Wageningen Netherlands.

3. Xavier Filho, J. (1992) The biological roles of serine and cysteine proteinase inhibitors in plants, vol. 4: Revista Brasileira De Fisiologia Vegetal (Londrina, ed.), Rev. Bras. Fisiol., pp. 1-6.

4. Koide, T., Ikenaka, T., \& Tsunasawa, S. (1973). Studies on soybean trypsin inhibitors 2. Amino-acid sequence around the reactive site of soybean trypsin inhibitor (Kunitz). European Journal of Biochemistry, 32(3), 408-416.

5. Song, S. I., Kim, C. H., Baek, S. J., \& Choi, Y. D. (1993). Nucleotide sequences of cDNAs encoding the precursors for soybean (Glycine max) trypsin inhibitors (Kunitz type). The Plant Cell, 101, 1401-1402.

6. Meester, P. D., Brick, P., Lloyd, L. F., Blow, D. M., \& Onesti, S. (1998). Structure of the Kunitz-type soybean trypsin inhibitor (STI): implication for the interactions between members of the STI family and tissue-plasminogen activator. Acta Crystallographica. Section D: Biological Crystallography, 54, 589-597.

7. Kunitz, M. (1945). Crystallization of a trypsin inhibitor from soybean. Science, 101(2635), 668-669.

8. Baintner, K. (1981). Trypsin-inhibitor and chymotrypsin-inhibitor studies with soybean extracts. Journal of Agricultural \& Food Chemistry, 29(1), 201-203.

9. Camarero, J., Shekhtman, A., Breindel, L., Aboye, T., \& Li, Y. (2016). Efficient recombinant expression of SFTI-1 in bacterial cells using intein-mediated protein trans-splicing. Biopolymers, 6, 818-824.

10. Chai, X. J., Chen, H. X., Xu, W. Q., \& Xu, Y. W. (2013). Expression of soybean Kunitz trypsin inhibitor gene SKTI in Dunaliella salina. Journal of Applied Phycology, 25, 139-144.

11. Burgess, E. P. J., Stevens, P. S., \& Keen, P. K. (2011). Effects of protease inhibitors and dietary protein level on the black field cricket Teleogryllus commodus. Entomologia Experimentalis et Applicata, 61, 123-130.

12. Kobayashi, H., Suzuki, M., Kanayama, N., \& Terao, T. (2004). A soybean Kunitz trypsin inhibitor suppresses ovarian cancer cell invasion by blocking urokinase upregulation. Clinical and Experimental Metastasis, 21(2), 159-166.

13. Falco, M. C., \& Silva-Filho, M. C. (2003). Expression of soybean proteinase inhibitors in transgenic sugarcane plants: effects on natural defense against Diatraea saccharalis. Plant Physiology and Biochemistry, 41, 761-766.

14. Franco, O. L., Dias, S. C., Magalhaes, C. P., Monteiro, A. C. S., Bloch, C., \& Melo, F. R. (2004). Effects of soybean Kunitz trypsin inhibitor on the cotton boll weevil (Anthonomus grandis). Phytochemistry, 65(1), $81-89$.

15. Chang, E. (2013). Enzymes used as ancillary materials in pharmaceutical manufacturing. USP, 39, 1-7.

16. Smith, P. K., Krohn, R. I., Hermanson, G. T., Mallia, A. K., Gartner, F. H., Provenzano, M. D., Fujimoto, E. K., Goeke, N. M., Olson, B. J., \& Klenk, D. C. (1985). Measurement of protein using bicinchoninic acid. Analytical Biochemistry, 150(1), 76-85.

17. Morita, S., Fukase, M., Hoshino, K., Fukuda, Y., Yamaguchi, M., \& Morita, Y. (1996). Partial purification and characterization of a novel soybean protease which is inhibited by Kunitz and Bowman-Birk trypsin inhibitors. The Journal of Biochemistry, 119(4), 711-718. 
18. Graf, L., Jancsó, A., Szilágyi, L., Hegyi, G., Pintér, K., Náray-Szabó, G., Hepp, J., Medzihradszky, K., \& Rutter, W. J. (1988). Electrostatic complementarity within the substrate-binding pocket of trypsin. Proceedings of the National Academy of Science of the United States of America, 85, 4961-4965.

19. Delarco, J. E., \& Liener, I. E. (1973). The involvement of an arginine residue of trypsin in its interaction with the Kunitz soybean trypsin inhibitor. Biochimica et Biophysica Acta: Protein Structure, 303, 274-283.

20. Rühlmann, A. (1973). Structure of the complex formed by bovine trypsin and bovine pancreatic trypsin inhibitor: crystal structure determination and stereochemistry of the contact region. Journal of Molecular Biology, 77, 417-436.

21. Baillargeon, M. W., Laskowski, M., Neves, D. E., Porubcan, M. A., Santini, R. E., \& Markley, J. L. (1980). Soybean trypsin inhibitor (Kunitz) and its complex with trypsin. Carbon-13 nuclear magnetic resonance studies of the reactive site arginine. Biochemistry, 5703-5710.

Publisher's Note Springer Nature remains neutral with regard to jurisdictional claims in published maps and institutional affiliations. 